\title{
A Note on Sources, Transliteration, and Dates
}

AT ITS CORE, this book is a transregional, connective, and comparative study. It situates the Hijaz and Arabian Red Sea littoral between two rival imperial powers, the Ottomans and the British. From a spatial perspective, the Hijaz appears as a liminal borderland between the Ottoman Empire's Arab frontiers and a British-dominated Indian Ocean. In order to represent some facsimile of the transregional, multiethnic, and multilinguistic texture of this time and place, the pages of this book are populated by a dizzying mélange of Ottoman officials, Arabs, Europeans, Indians, Jawis, and diasporic Hadramis. To strike a balance between these overlapping worlds, I conducted the bulk of my research at the Başbakanlık Osmanlı Arşivi (now the Türkiye Cumhuriyeti Cumhurbaşkanlığı Devlet Arşivleri) in Istanbul and the National Archives of the United Kingdom (formerly the Public Record Office) at Kew. In addition to these two main collections, I also used the British Library's Asia, Pacific, and Africa Collections (India Office Records) and the Thomas Cook Group Archives (now part of the Record Office for Leicestershire, Leicester and Rutland). I was also fortunate to be invited to examine a private collection of letters, photographs, and ephemera held by the Khalili Family Trust's Hajj and the Arts of Pilgrimage Collection. In Istanbul I also made use of the Beyazit Devlet Kütüphanesi and the İslam Araştırmaları Merkezi (ISAM).

This book draws on archival and published primary and secondary sources in Ottoman Turkish, modern Turkish, and Arabic. In translating 
and transliterating these materials, in general I have been faithful to the International Journal of Middle East Studies transliteration guidelines. Where feasible, I have tried to make terms from these languages as accessible as possible to nonspecialist readers. Thus when Turkish or Arabic words have been adopted widely in English, I have opted for the commonly understood English version-for example, hajj, not hajj or hacc; sharif, not sharif or şerif; pasha, not paşa; and jihad, not jihäd or cihad.

Because Ottoman and modern Turkish are the primary research languages featured throughout this study, I have opted for Turkish rather than Arabic spellings of technical terms, legal concepts, and governmental jargon. However, in some cases I have also deployed Arabic terminologies and spellings.

For place names I have generally opted for spellings most commonly adopted in English. Likewise, place names follow their primary linguistic affiliation. Thus for Arabic-speaking places I have opted for Jeddah, not Cidde, and Hijaz instead of Hicaz.

For individual names and titles, however, things get a bit trickier. I have tried to transliterate titles and proper names in a way that reflects each individual's primary official or linguistic affiliation. All Ottoman officials' names are rendered with Ottoman-Turkish spellings. For example, we find Mehmed Ali Pasha, not Muhammad 'Alī. By contrast, for the Arabic-speaking cultural milieu of the Hijaz, I refer to 'Awn al-Rafīq, the sharif of Mecca, not Avnürrefik Pasha, the Şerif of Mekke.

Finally, this study includes the names of a great many colonial subjects either working for or receiving protection from the British consulate in Jeddah. For these names I have retained the Latin transliterations used in British documents. Thus for the Indian Muslim vice-consul, I use Dr. Abdur Razzack instead of Dr. 'Abd al-Razzāq. Likewise, for the British translator at Jeddah, I refer to Yusuf Kudzi and not Yūsuf Qudsī. At least part of the logic behind retaining these idiosyncratic nineteenth-century spellings is to ensure that readers with an interest in the British Empire will be able to locate and match these names with other archival and secondary materials. However, for diasporic figures such as Sayyid 'Umar al-Saqqāf or Omar alSagoff, who is known in Hadrami-Hijazi circles but is equally well known in the historiography of Singapore and Southeast Asia, I have provided both spellings. 
Common Era (Gregorian) dates are used throughout the text. In citing Ottoman-Turkish and Arabic documents and secondary sources, I give the full hijri date followed by the Common Era date. The vast majority of the Ottoman documents and other sources cited throughout the text follow the hijrì Islamic lunar calendar. However, a handful of Ottoman sources refer to the solar-based Ottoman Rumi calendar (also known as the Maliye or fiscal calendar).

Hijrī Calendar Months in Ottoman Turkish/Arabic

M: Muharrem/Muharram

S: Safer/Ṣafar

Ra: Rebiülevvel/Rabī` al-Awwal

R: Rebiülahir/Rabī‘ al-Ākhir

Ca: Cemaziyelevvel/Jumādā al-Ūlā

C: Cemaziyelahir/Jumādā al-Ākhira

B: Receb/Rajab

Ş: Şaban/Sha'bān

$\mathrm{N}$ : Ramazan/Ramadān

L: Şevval/Shawwāl

Za: Zilkade/Dhū al-Qa'da

Z: Zilhicce/Dhū al-Hijja 
